\title{
ESPAÇO PARA A MORTE. O TERRAÇO DA FOZ DO MEDAL (VALE DO SABOR, NORDESTE DE PORTUGAL) DURANTE A IDADE DO BRONZE
}

\author{
RITA GASPAR $^{(1)}$, JOANA CARRONDO $^{(1),(2)}$, LUÍS NOBRE $^{(1),(2)}$, ZÉLIA RODRIGUES $^{(3)}$ \& GLÒRIA DONOSO ${ }^{(1)}$
}

Resumo:

\begin{abstract}
A intervenção arqueológica no Terraço da Foz do Medal decorreu no âmbito das medidas de minimização patrimoniais aplicadas no projeto de construção do Aproveitamento Hidroelétrico do Baixo Sabor (AHBS). A intervenção revelou uma importante ocupação da Idade do Bronze materializada num conjunto de estruturas negativas de tipo fossa. Quatro dessas estruturas apresentavam enterramentos primários, três individuais e um duplo, nomeadamente de 1 sub-adulto e 4 adultos. Este artigo apresenta especificamente o espaço reservado aos mortos dentro desta jazida.
\end{abstract}

Palavras-chave: Idade do Bronze, enterramentos, vale do Sabor, nordeste de Portugal.

Abstract:

\begin{abstract}
Place for death. The Terraço da Foz do Medal (Sabor valley, northeast of Portugal) during the Bronze Age The following work was carried out as part of a project to register the heritage that is going to be affected by the construction of a hydroelectric dam on the river Sabor in north-eastern Portugal. The work carried out at the river terrace of Foz de Medal revealed a Bronze Age occupation consisting on a concentration of negative structures, 4 of which contained the remains of 5 individuals ( 4 adults and 1 sub-adult). These will be presented here.
\end{abstract}

Keywords: Bronze Age; human burials; Sabor valley, northeast Portugal.

Received: 22 January 2014; Accepted: 3 March 2014

\section{INTRODUÇÃ̃O}

A ocupação da Idade do Bronze no Terraço da Foz do Medal (Meirinhos, Mogadouro) foi identificada no decorrer do programa de sondagens de diagnóstico aplicado aos terraços fluviais do vale do Sabor. Este programa de minimizações de impacte desenvolveu-se no âmbito do Plano de Salvaguarda do Património (PSP), aplicado ao projeto de construção do Aproveitamento Hidroeléctrico do Baixo Sabor (AHBS) promovido pela EDP e implementado pelo consórcio construtor Baixo Sabor-ACE. A intervenção arqueológica decorreu entre 2011 e 2013 com a parceria das empresas Archeoestudos, Lda e Arqueologia e Património, Lda.

O Terraço da Foz do Medal localiza-se na margem esquerda do rio Sabor, freguesia de Meirinhos, concelho de Mogadouro, distrito de Bragança, às coordenadas geográficas $6^{\circ}$ 52' $52,599^{\prime}$ 'W, $41^{\circ} 15^{\prime} 17,344^{\prime}$ 'N (Sistema de referência PT-TM06-ETRS89) (Fig.1). O sítio implanta-se na confluência das ribeiras de Pedra de Asma e do Medal com o rio Sabor, a uma cota absoluta que varia entre os $163 \mathrm{~m}$ e $166 \mathrm{~m}$ acima do nível médio das águas do mar. Esta plataforma aplanada situa-se no fundo do vale do Sabor, apenas oito metros acima do curso de água atual. Encontra-se delimitada a norte pela linha de água principal (o rio Sabor), a oeste pela foz da ribeira do Medal, a sul pela ribeira de Pedra de Asma e a este pela presença de uma acentuada vertente de substrato xistoso. Estes elementos naturais estruturam o espaço ocupado pelas comunidades pré-históricas na ampla diacronia identificada na plataforma.

De um modo geral, o rio Sabor desenvolve-se num vale bastante encaixado, ainda que com uma importante variedade geomorfológica que se reflete claramente nas estratégias de ocupação do vale pelas comunidades paleo-humanas. Localiza-se na área marginal da superfície aplanada da Meseta, onde uma forte drenagem fluvial e importantes deslocações tectónicas relacionadas com o desligamento tardivarisco de Bragança-Manteigas tornam o relevo muito acidentado (FERREIRA 2005). A área apresenta grandes desníveis (na ordem dos 700 a $800 \mathrm{~m}$ ) sobretudo na envolvente do rio Sabor (SiLva et al. 1989), contrastando com o território aplanado (peneplanície da Meseta) a leste do mesmo curso de água (PEREIRA et al. 2008).

\footnotetext{
Baixo Sabor-ACE. E-mail: ritantunesgaspar@gmail.com

UTAD - Universidade de Trás-os-Montes e Alto Douro

Arqueologia e Património, Lda.
} 


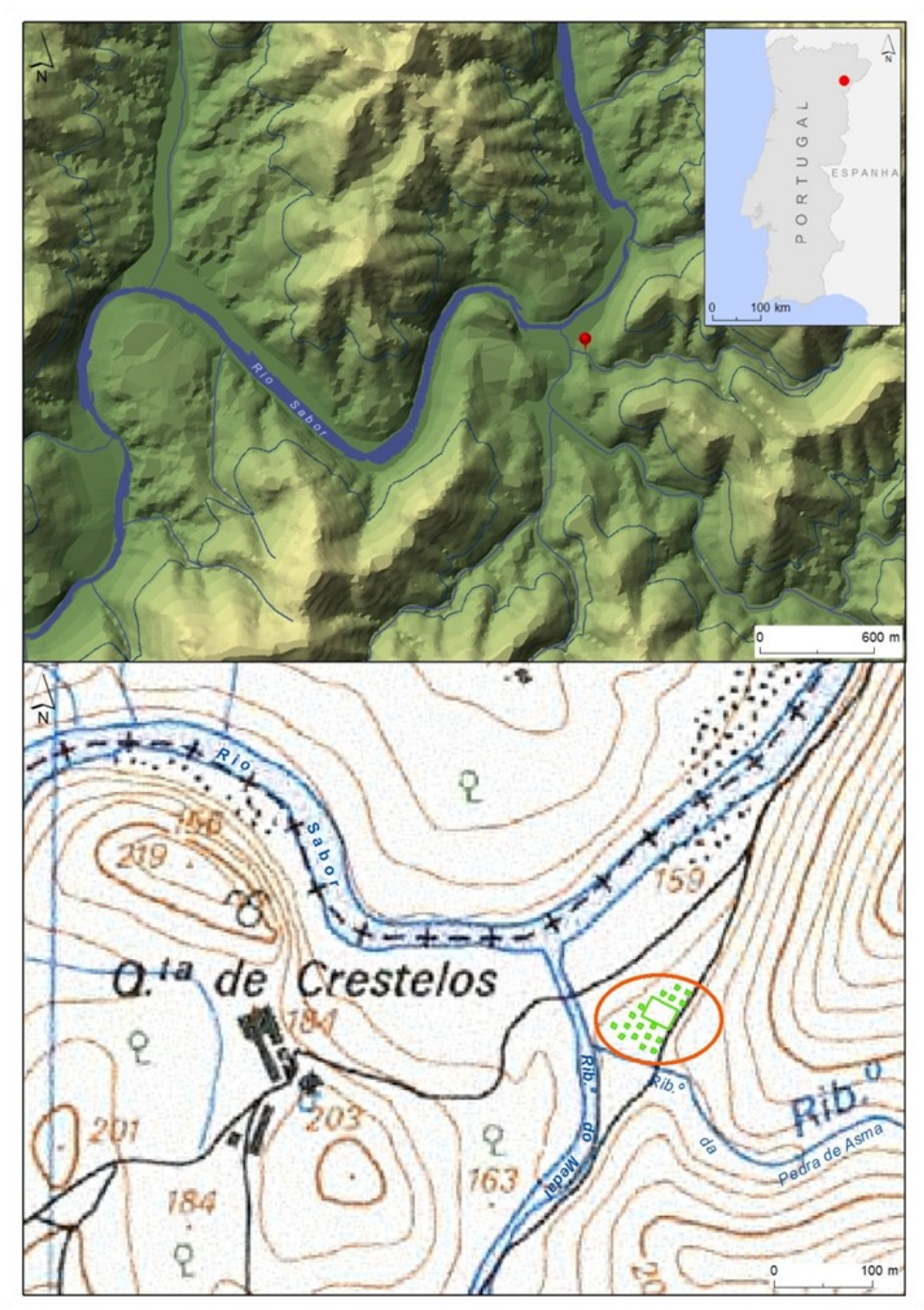

Fig. 1. Localização do Terraço da Foz do Medal na margem esquerda do rio Sabor (superior) e implantação do sítio arqueológico num extrato da Folha 119 - Felgar (Torre de Moncorvo) da CMP (inferior). (Cartografia por Ana Rita Ferreira).

Fig. 1. Location of Terraço da Foz do Medal on the left bank of the river Sabor (upper) and position of the site on Folha 119 - Felgar (Torre de Moncorvo) da CMP (inferior) (Map by Ana Rita Ferreira).

O vale do Sabor, com um perfil predominante em $\mathrm{V}$ e desníveis muito consideráveis entre o fundo do vale e as superfícies aplanadas localizadas nos topos, apresenta também três áreas com condições geomorfológicas distintas, decorrentes precisamente das condições específicas deste território, sejam as distintas resistências apresentadas pelas litologias que o curso de água atravessa ou a neotectónica ativa (PEREIRA E AZEVÊDO 1995). Nestas áreas (Fig.2) o vale apresenta-se mais aberto tendo sido permitida a formação de amplas plataformas de origem fluvial. As boas condições de habitabilidade destas plataformas e a possibilidade de exploração de recursos bióticos e/ou abióticos justificam a utilização recorrente deste espaço. Sendo escassas na região, estas áreas são ocupadas de forma intensiva pelas populações desde época Pré-Histórica.

$\mathrm{O}$ troço do vale onde se localiza a confluência entre a foz da ribeira do Medal e o rio Sabor é disso um excelente exemplo. Na margem direita do rio Sabor desenvolve-se um amplo terraço quaternário onde foi recolhido um conjunto material lítico enquadrado no Paleolítico antigo (intervencionado pela primeira signatária), sendo que no topo do terraço foi edificada, no séc. XVIII, a capela de Santo Antão (TRINDADE et al. 2012) símbolo derradeiro da sacralização deste ponto específico do vale, travessia natural do rio Sabor. Em ambas as margens do rio Sabor, bem como nas ribeiras que se desenvolvem na sua margem esquerda, surgem afloramentos com grafismos rupestres de cronologia holocénica destacando os zoomorfos de Cabeço do Aguilhão e 
de Santo Antão da Barca (FIGUEIREDo 2013). A densidade de rochas gravadas neste troço do vale parece também indicar uma marcação específica desta paisagem. Na margem esquerda do rio principal localizamse dois dos mais importantes sítios arqueológicos intervencionados no vale. O Terraço da Foz do Medal apresenta vários níveis com ocupação paleo-humana abarcando uma ampla sequência do Paleolítico superior que culmina com uma importante ocupação da fase final deste período, onde foi identificado um conjunto de arte móvel gravada (GASPAR, no prelo; FIGUEIREDO et al. 2014) com cerca de 1500 fragmentos de placas de xisto e grauvaque e mais de 250000 elementos de pedra lascada. Sobre esta sequência desenvolve-se uma ocupação da Idade do Bronze, onde se encontraram os contextos funerários que são alvo deste trabalho. A jusante localiza-se a Quinta de Crestelos, uma importante propriedade de cariz rural, onde também foram identificados vestígios de uma ocupação pré-histórica a par de uma importante ocupação da Idade do Ferro. Nesta plataforma e crista rochosa associada foi identificada uma longa sequência, com especial relevância para as fases da Idade do Ferro e período romano (SASTRE, no prelo).

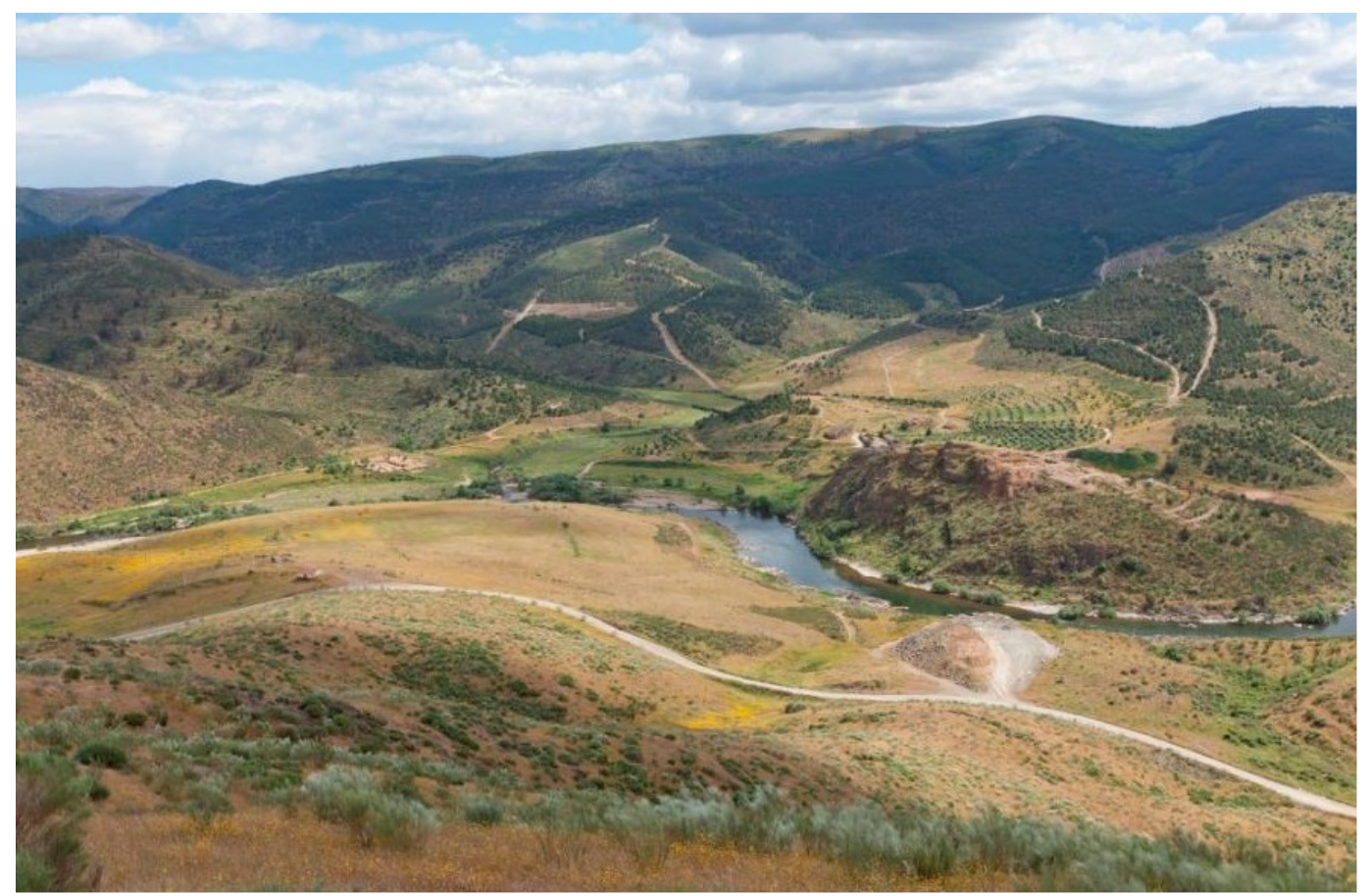

Fig. 2. Vista geral, para sudeste, do vale do Sabor. A seta localiza o Terraço da Foz do Sabor (Fotografia de Adriano Borges).

Fig. 2. South-westerly view of the Sabor valley. The arrow marks the location of Terraço da Foz do Sabor (Photo by Adriano Borges).

\section{CONTEXTOS DA IDADE DO BRONZE}

Os trabalhos de escavação em área iniciaram-se em dezembro de 2011 com objetivo de caracterizar os contextos da Pré-história Antiga identificados em sondagens de diagnóstico. No decorrer da intervenção foi identificada uma ocupação da Idade do Bronze, caracterizada por um conjunto de estruturas negativas, dispersas pela plataforma. Estas foram escavadas nos depósitos fluviais de matriz fina apresentando dimensões variadas, mas na sua maioria de perfil tendencialmente cilíndrico. Associada a esta ocupação da plataforma surgiram também seis estruturas de combustão em covacho, com preenchimento de termoclastos. O topo desta ocupação encontrava-se bastante alterado, não tendo sido identificadas estruturas em positivo. Registaram-se apenas acumulações de grandes lajes de xisto que se encontravam em posição vertical ou subvertical, apresentando uma inclinação que acompanhava o sentido da vertente. Estas estavam associadas aos níveis de enchimento das fossas. As características específicas desta ocupação da Idade do Bronze não serão abordadas neste estudo, que se destina apenas a divulgar os contextos funerários.

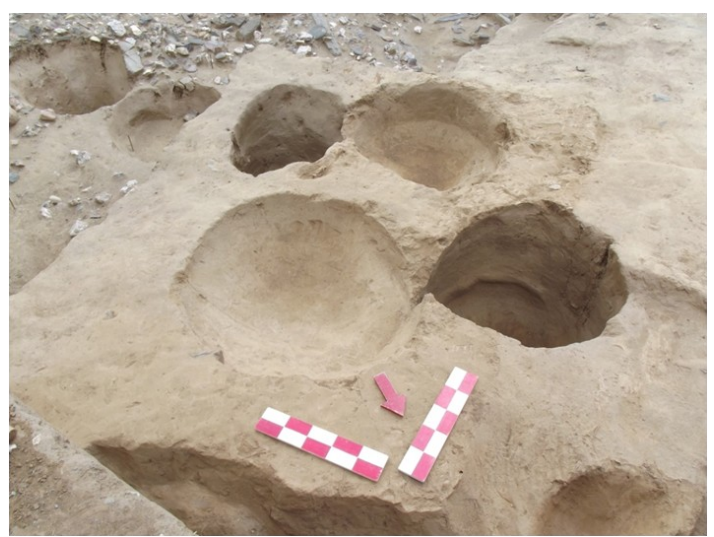

Fig. 3. Estruturas negativas da Idade do Bronze identificadas na plataforma. Fig. 3. Bronze Age pits identified in the river terrace. 
A sequência estratigráfica da plataforma é bastante desenvolvida e complexa, composta predominantemente por depósitos finos de origem aluvionar, com alguns contributos de vertente. A ocupação da Idade do Bronze dá-se no topo da sequência aluvionar fina, utilizando os siltes para abrir as estruturas negativas (Fig. 4). Estas estruturas cortam os depósitos de cronologia paleolítica existentes, e surgem parcialmente afetadas pelo plantio de vinha em época contemporânea.

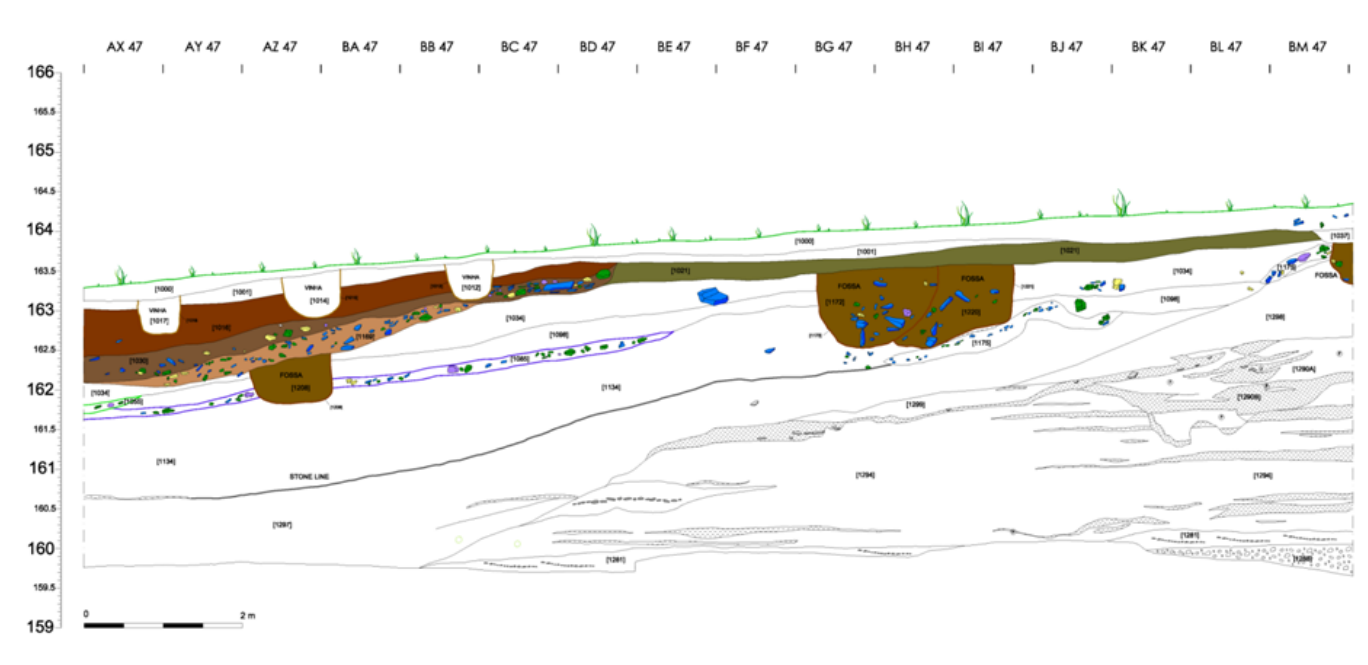

Fig. 4. Pormenor da sequência estratigráfica do Terraço da Foz do Medal com a localização dos contextos da Idade do Bronze. A castanho algumas das fossas identificadas, abertas no depósito fino de topo de sequência fluvial. Este nível é coberto por depósitos de origem coluvionar (Desenho de Patricia Fuentes Melgar).

Fig. 4. Stratigraphical sequence of the site with the location of the Bronze Age contexts. The pits/negative structures are represented in brown, and were covered by fine deposits from the top of the fluvial sequence. This level is covered by colluvium deposits (Drawing by Patricia Fuentes Melgar)

Do ponto de vista morfológico as 69 fossas identificadas apresentam plantas circulares ou ovais, variando os perfis. Estão presentes perfis cilíndricos, de paredes retas e fundo plano, globulares, em cone, e troncocónicos (estes últimos são mais raros). Os diâmetros das fossas variam entre os 80 e os $180 \mathrm{~cm}$, e a profundidade entre os $14 \mathrm{~cm}$ e os $158 \mathrm{~cm}$. É provável, no entanto, que o topo de algumas fossas esteja truncado pelo que a profundidade registada nem sempre corresponderá à profundidade original da estrutura. Algumas destas estruturas negativas estão relacionadas com uma ocupação holocénica anterior, nomeadamente o núcleo identificado a oeste na plataforma (cf Fig. 6).

Das 69 estruturas negativas de tipo fossa identificadas, quatro continham enterramentos (uma criança, uma mulher adulta, um enterramento duplo de um casal e um indivíduo adulto de sexo indeterminado) associados à ocupação da idade do Bronze. O outro enterramento identificado, uma criança no núcleo de estruturas a sul, encontra-se associado a uma ocupação de cronologia anterior. Algumas fossas apresentam vestígios de combustão na sua base, sendo que os macrorrestos vegetais recolhidos encontram-se em análise. Existem ainda vestígios de possíveis revestimentos das estruturas com lajes de grauvaque e xisto tendo sido identifi- cado o seu abatimento no interior. Algumas destas lajes apresentam mesmo revestimentos carbonatados em metade da superfície, indicando que estariam apenas parcialmente enterradas aquando da utilização das estruturas.

O conjunto material relacionado com a ocupação da Idade do Bronze é bastante escasso, tendo sido identificado na sua quase totalidade nos depósitos coluvionares que cobrem as estruturas negativas. Trata-se de um conjunto com 171 fragmentos de recipientes cerâmicos, sendo que apenas 32 fragmentos foram recolhidos nos depósitos de enchimento das fossas. O mau estado de preservação dos fragmentos inviabiliza à partida uma análise detalhada. Do reduzido número de fragmentos onde foi possível averiguar a forma do recipiente é notório o domínio de formas abertas. Predomina a decoração incisa, estando também presente a impressa e a excisa. Os motivos identificados incluem bandas paralelas, bandas paralelas com motivos triangulares, espigas e cordão plástico. A maior parte do conjunto cerâmico recolhido parece remeter para um contexto do período Proto-Cogotas (Fig. 5: 2 e 3), no entanto, foram igualmente identificados alguns fragmentos que se enquadram já no período Cogotas I (Fig. 5: 1 e 4). 


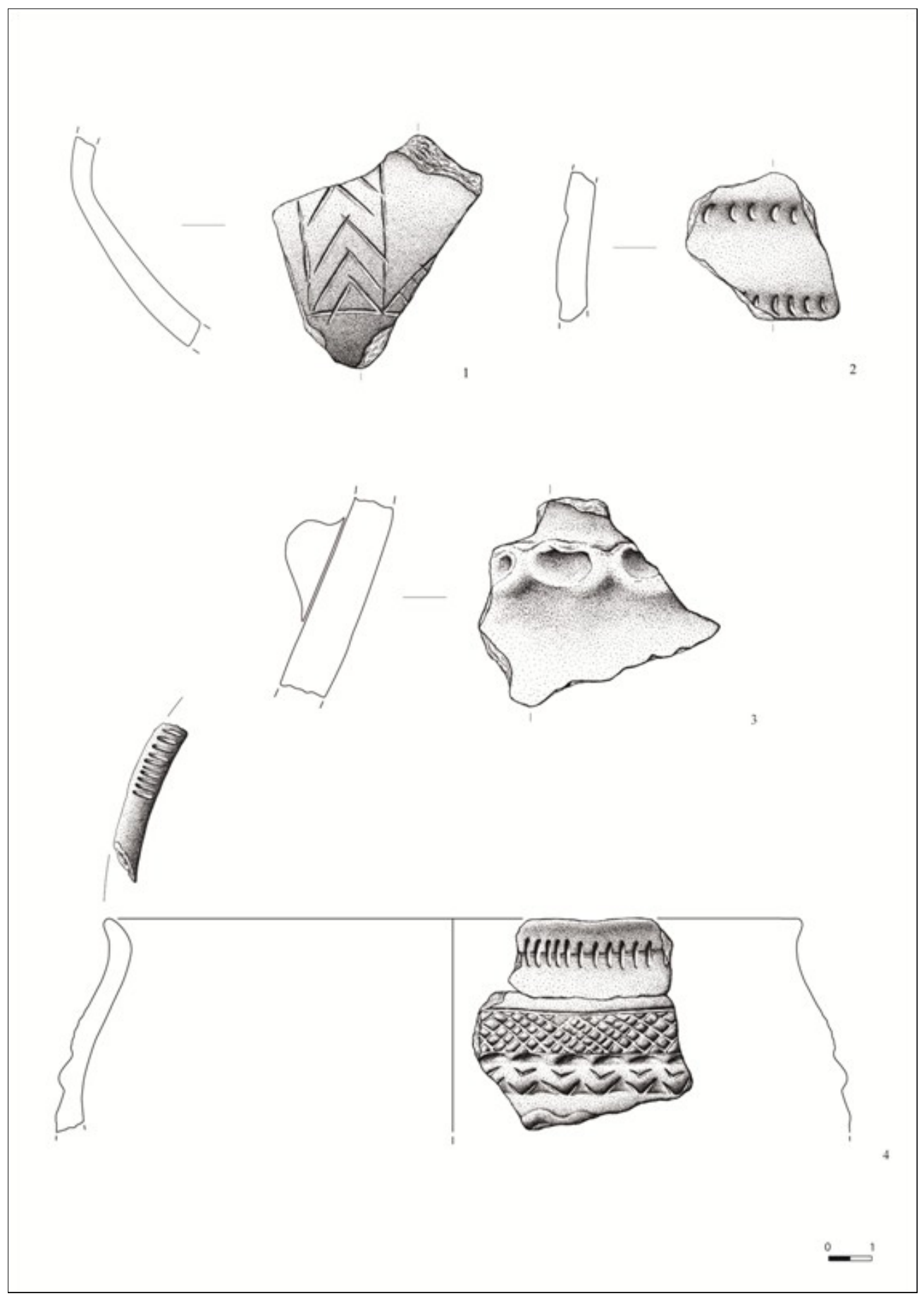

Fig.5. Fragmentos de recipientes cerâmicos recolhidos (desenhos de Patricia Fuentes Melgar).

Fig. 5. Fragments of ceramic vessels recovered during the excavation (drawings by Patricia Fuentes Melgar).

\section{CONTEXTOS FUNERÁRIOS}

Os cinco enterramentos identificados e exumados apresentavam, de um modo geral, um excelente estado de conservação. Trata-se de inumações primárias, encontrando-se preservadas conexões anatómicas e articulações lábeis tais como ossos das mãos e dos pés.
Todos os indivíduos foram inumados em estruturas negativas de tipo fossa, correspondendo às fossas 1, 16, 28 e 61 . A sua distribuição pela plataforma (Fig. 6) não parece obedecer a critérios espaciais específicos, pelos menos reconhecíveis por ora. No entanto, é possível observar que os enterramentos 1 (fossa 1), 2, 3 (fossa 16) e 4 (fossa 61) surgem numa localização bastante central na 
ocupação. Tendo em conta que não foi possível identificar a presença de estruturas de cariz claramente habitacional, quer seja pela sua ausência do registo arqueológico ou por questões de erosão pos -deposicional (das quais existem inúmeros vestígios na plataforma), não é também possível estabelecer relações espaciais entre os contextos funerários e os restantes identificados.

Tabela 1. Características das fossas com enterramentos Table 1. Characteristics of burial pits

\begin{tabular}{|c|c|c|c|c|c|c|}
\hline No Fossa & Perfil & Fundo & $\begin{array}{c}\text { Ø Boca } \\
\text { (Metros) }\end{array}$ & $\begin{array}{c}\text { Ø Base } \\
\text { (Metros) }\end{array}$ & Prof. & $\begin{array}{c}\text { Preservação Morfologia } \\
\text { Original }\end{array}$ \\
\hline 1 - U.E. [1033] & Globular & Concavo & 1.05 & 1.00 & 0.14 & Não \\
\hline 16 - U.E. [1124] & Em cone & Concavo & 1.80 & 0.50 & 1.15 & Sim \\
\hline 28 - U.E. [1177] & Em campânula & Plano & 0.80 & 1.30 & 0.90 & Não \\
\hline 61 - U.E. [1156] & Globular & Plano & 1.20 & 0.90 & 0.12 & Nam \\
\hline
\end{tabular}

Nenhuma fossa apresenta vestígios de revestimento com argila. Quatro dos cinco enterramentos exumados encontravam-se inumados em três fossas que apresentavam grandes lajes de xisto (com comprimento máximo que rondava os $80 \mathrm{~cm}$ ). A presença destas lajes e a sua posição indica a existência de uma estruturação intencional. Situações idênticas estão referenciadas noutros sítios peninsulares com contextos funerários (BLASCO et al. 1991; BLASCO 1997; PRIETO et al. 2009; SANTOS et al. 2009), onde se identificaram acumulações pétreas, cuidadosamente colocadas sobre os enterramentos.

As lajes não foram observadas na sua posição original encontrando-se no centro da fossa em posição sub-vertical, como resultado de um abatimento. Possivelmente estas estariam dispostas na vertical a revestir a boca da fossa. Na verdade, a fossa que apresentava uma estruturação melhor preservada era a fossa 16, que continha o enterramento 2 (indivíduo adulto do sexo feminino). A fossa apresenta uma boca com morfologia circular e $180 \mathrm{~cm}$ de diâmetro, um metro de profundidade e perfil cilíndrico. No topo da fossa encontrava-se um montículo de seixos de quartzo e quartzito assim como blocos de grauvaque, abaixo deste e junto ao enterramento estavam diversas lajes de xisto dispostas em X que cobriam a inumação.

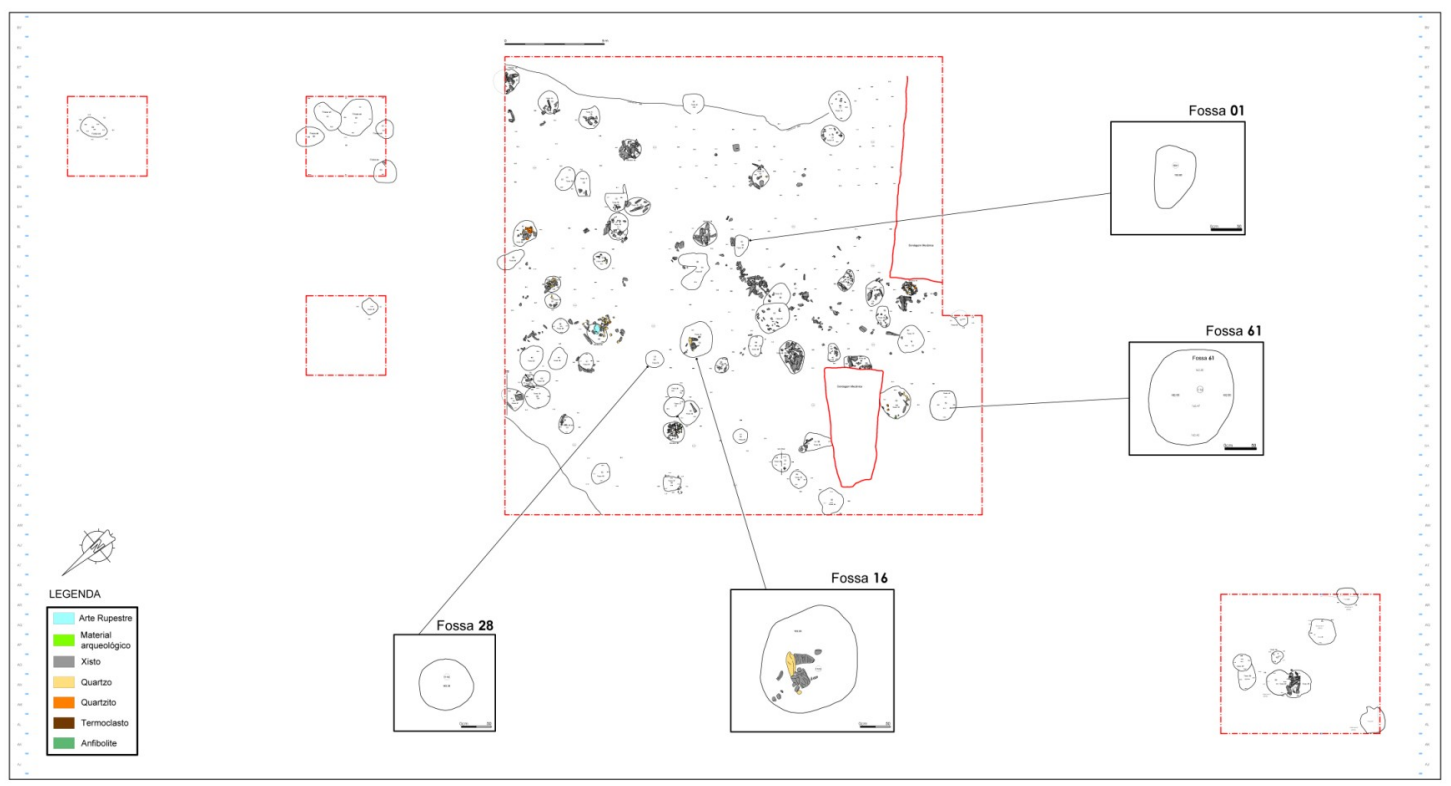

Fig. 6. Distribuição das estruturas negativas registadas na plataforma e identificação das fossas com enterramentos. (Desenho de Patricia Fuentes Melgar)

Fig. 6. Distribution of pits and burial pits (enlarged) excavated in the platform (Drawing by Patricia Fuentes Melgar). 


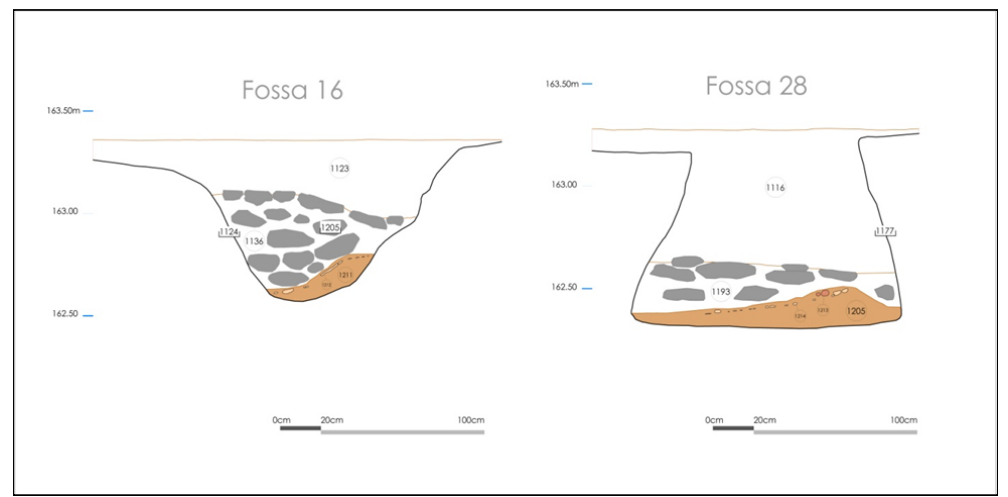

Fig. 7. Perfis das fossas de inumações que apresentam estruturação interna (Desenhos de Patricia Fuentes Melgar).

Fig. 7. Sections of the burial pits which contained internal structures (Drawing by Patricia Fuentes Melgar).

A fossa 28, que continha um enterramento duplo, apresentava também indícios de estruturação, com presença de blocos de xisto e grauvaque, que se encontravam na horizontal, à exceção de uma laje de grauvaque que estava na vertical encostada à parede da fossa. Ao contrário da estrutura anterior esta registava uma boca mais estreita ( $80 \mathrm{~cm}$ de diâmetro), também circular e as paredes retas que se tornavam mais largas à medida que se aproximavam da base plana.

Estas lajes de grauvaque deveriam, em alguns casos, estar parcialmente expostas, i.e., parcialmente fora da fossa. Esta situação é indiciada pela presença de revestimentos carbonatados em algumas lajes.

\subsection{Enterramento 1}

O indivíduo [1032] foi inumado na fossa 1, com a orientação sudeste (crânio)- noroeste (pés). Apresentava-se com o tronco em decúbito dorsal e o crânio sobre o lado esquerdo com a face voltada a sudoeste. Os membros superiores estavam completamente fletidos para o lado esquerdo, com a mão direita a repousar sobre as primeiras costelas direitas e a esquerda sob o crânio, e os inferiores fletidos para o mesmo lado.

$\mathrm{O}$ esqueleto encontra-se bastante completo, tendo sido recuperados todos os elementos ósseos constituintes do esqueleto humano a exceção do esterno, das rótulas e de alguns ossos das mãos e dos pés. As peças ósseas recuperadas exibem um razoável estado de conservação, sendo as diáfises dos ossos longos as que melhor se conservaram

A análise paleodemografica, in situ, revelou tratar-se de um indivíduo sub-adulto, com provável idade a morte a rondar os 8-9 anos ( \pm 2 anos), a avaliar pelo processo de calcificação e erupção dentária. Este diagnóstico é corroborado pelos comprimentos máximos diafisiários dos ossos longos dos seus membros superiores e inferiores. Tendo em conta tratar-se de um indivíduo sub-adulto não foi possível determinar o sexo nem a estatura. Torna-se também inviável o cálculo dos índices de robustez e achatamento dos ossos longos e consequente estudo dos padrões de atividade das populações.

Uma observação sumária dos vários elementos ósseos recuperados não revelou a presença de quaisquer evidências de cariz paleopatológico.

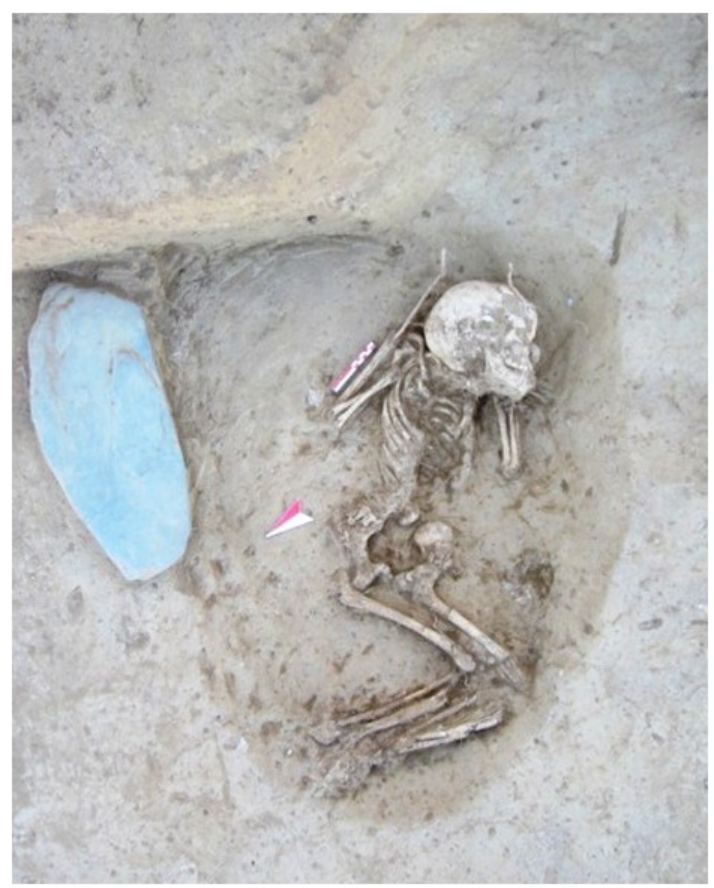

Fig. 8. Enterramento 1- Indivíduo sub-adulto Fig. 8. Burial 1 - A sub-adult. 


\subsection{Enterramento 2}

O indivíduo [1212] foi inumado na fossa 16 em posição de decúbito lateral esquerdo, numa orientação sudeste (crânio) - noroeste (pés), com o crânio sobre o lado esquerdo e a face voltada a nordeste. Os membros superiores encontravam-se fletidos para o lado esquerdo, com o direito a sobrepor-se ao esquerdo e as mãos junto a face. Os membros inferiores estão fletidos para o mesmo lado com os ossos longos do direito sobre os do esquerdo. Este esqueleto estava completo, tendo sido recuperadas todas as peças ósseas constituintes do esqueleto humano, as quais exibem um bom estado de conservação.

A análise morfológica aos ilíacos, ossos mais discriminantes neste exercício, permitiu determinar o sexo feminino para este indivíduo. Estes elementos exibem características típicas deste sexo, designadamente, a grande chanfradura ciática em forma de U, o arco composto duplo e o acetabulo peque-

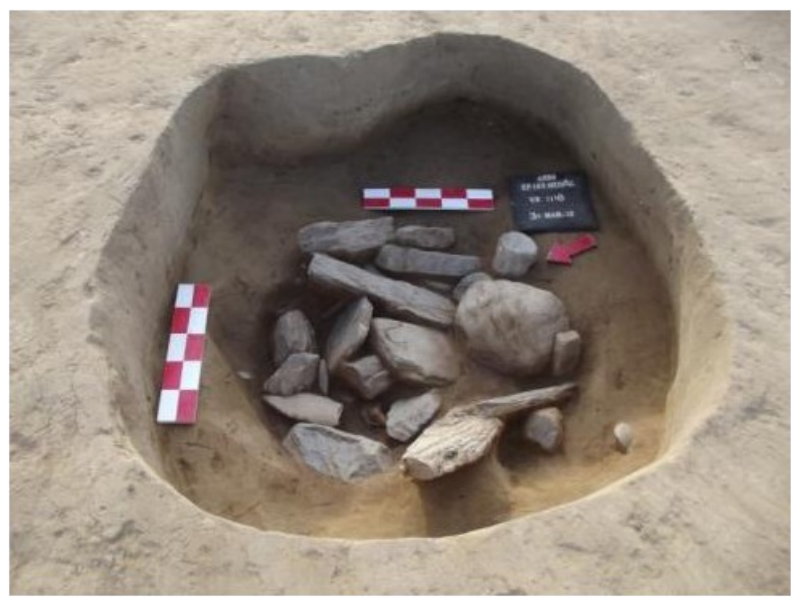

no. Esta diagnose é corroborada pelas análises morfológicas ao crânio, elemento ósseo a seguir aos ossos da bacia mais fiável a este exercício (arcadas supraciliares pouco marcadas, inion pouco saliente e apófises pouco robustas) e métricas aos úmeros, aos fémures e aos calcâneos.

As extremidades esternais das clavículas encontram-se encerradas permitindo estabelecer o limite inferior da idade da morte nos 30 anos. As metamorfoses das superfícies auriculares dos ilíacos, numa análise preliminar, aparentam ser compatíveis com uma idade a morte entre os 30-40 anos, a qual é corroborada pelo fato das suturas cranianas ainda não estarem obliteradas.

Morfologicamente esta mulher caracteriza-se por possuir uma estatura que situaria entre os $155,36 \mathrm{~cm}$ e os $158,12 \mathrm{~cm}$ determinada a partir dos comprimentos máximos do úmero $(290 \mathrm{~mm})$, fémur (425 mm) e tíbia (340 mm) esquerda. Quanto aos caracteres morfológicos não métricos refirase a presença de $3^{\circ}$ trocanter no fémur direito.

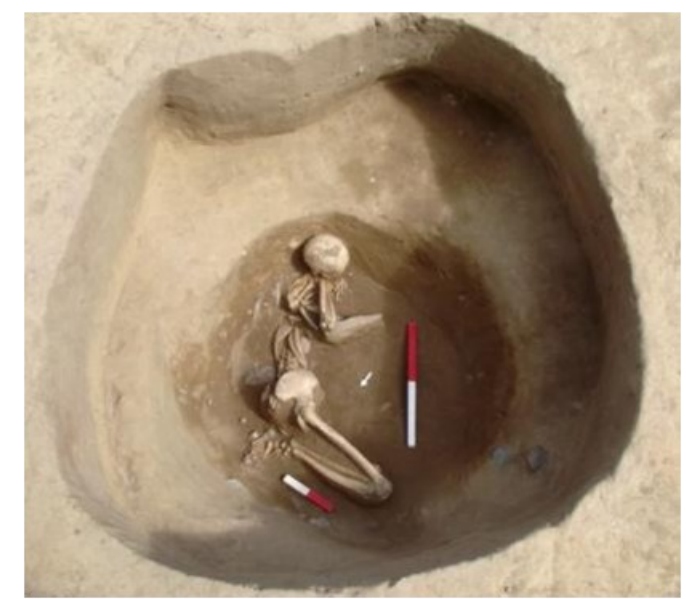

Fig. 9 e 10. Enterramento 2. Sepultura em estrutura negativa tipo fossa (esquerda) e enterramento de indivíduo adulto do sexo feminino (direita).

Fig. 9 and 10. Burial 2. Internal structure of a burial pit (left) and the burial of a female adult (right).

Nas peças ósseas recuperadas para este indivíduo foram detetadas evidências patológicas de cariz oral, degenerativo e, provavelmente, infecioso. As peças dentárias permanecem, aparentemente, todas in situ, e não exibem tártaro nem lesões cariogenicas. $\mathrm{O}$ desgaste dentário é de um modo geral, moderado a acentuado. As evidências de patologia degenerativa surgem sob a forma de artrose ligeira, nas articulações da anca, do joelho e do tornozelo direitos, traduzindo as marcas identificadas num ligeiro picotado vascular e moderada na articulação do tornozelo esquerdo.
Destaca-se a identificação, nas diáfises da tíbia e do perónio esquerdos, de marcas, aparentemente, compatíveis com periostite e que se traduzem numa estriação longitudinal ligeira e remodelada.

Deste enterramento foi obtida uma data por AMS Centre for Isotope Research (University of Groningen), tendo sido usada a curva de calibração de REIMER et al. 2013 - Calib radiocarbon calibration program (Calib Rev 7.1.0.) (Tab. 2).

Tabela 2. Datação absoluta obtida para o enterramento 2

Table 2. Absolute date obtained for burial 2

\begin{tabular}{|c|c|c|c|c|}
\hline $\begin{array}{c}\text { Ref. } \\
\text { Laboratório }\end{array}$ & $\begin{array}{c}\text { Contexto } \\
\text { arqueológico }\end{array}$ & Data BP & Cal. BC (1 sigma) & Cal. BC (2 sigmas) \\
\hline GrA - 54503 & $\begin{array}{c}\text { Fémur direito - Indivíduo [1212] } \\
\text { Enterramento 2, fossa 16 }\end{array}$ & $3385 \pm 35$ & $1695-1636(76 \%)$ & $1768-1610(99,2 \%)$ \\
\hline
\end{tabular}




\subsection{Enterramentos 3 e 4}

O indivíduo [1213] foi inumado na fossa 28 com o indivíduo [1214]. Apresentam orientação sudoeste(crânio)-nordeste(pés), ambos com o tronco em decúbito dorsal. O crânio sobre a base a descrever uma ligeira inclinação para o lado esquerdo, no caso do indivíduo [1213], e o crânio deposto sobre o lado direito com a face voltada a sudeste, no caso do indivíduo [1214].

O indivíduo [1213] (à esquerda na Fig. 12) apresenta o membro superior direito fletido para o lado direito num ângulo de aproximadamente $45^{\circ}$ e a mão a repousar sobre as primeiras vértebras torácicas e o membro superior esquerdo esticado e paralelo ao corpo com a mão sobre o ilíaco esquerdo. Os membros inferiores apresentavam-se fletidos para o lado esquerdo, depositados sobre os do indivíduo [1214] com o pé esquerdo, sob o membro inferior direito deste último indivíduo.

$\mathrm{O}$ esqueleto encontra-se completo, tendo sido recuperados todos os seus elementos ósseos em excelente estado de conservação. Pertence a um indivíduo do sexo feminino, a avaliar pelas características morfológicas dos ilíacos e do crânio e pelas análises métricas ao úmero, ao fémur e ao calcâneo esquerdos, com idade a morte entre os 21 e os 30 anos, uma vez que as epífises esternais das clavículas não estão fundidas e os terceiros molares superiores já erupcionaram e a crista ilíaca de ambos os ilíacos já está encerrada. A estatura desta mulher foi determinada a partir dos comprimentos máximos do úmero (320 mm), do fémur $(430 \mathrm{~mm})$ e da tíbia (362) esquerda e oscilaria entre os $159,30 \pm 5,96 \mathrm{~cm}$ e os $162,04 \pm 7,70 \mathrm{~cm}$. Morfologicamente, caracteriza-se ainda por possuir foramina parietal, perfuração esternal e abertura septal no úmero direito. No âmbito da análise paleopatologica foram detetadas algumas lesões, não muito graves, de cariz degenerativo (artrose e entesopatias) e oral.

$\mathrm{A}$ análise às superfícies articulares preservadas, permitiu identificar marcas compatíveis com artrose de grau 1 na articulação do cotovelo direito e moderada a acentuada (graus 2/3) nos condilos mandibulares. No esqueleto axial foi também observada artrose ligeira (grau 1), nas vertebras cervicais. Ainda no âmbito da patologia degenerativa foi observado o desenvolvimento de entesopatias de grau 1 no tendão de Aquiles do calcâneo esquerdo.

As peças dentárias deste indivíduo ainda permanecem todas in situ, à exceção do segundo pré-molar direito e dos primeiros e dos segundos molares superiores que sofreram, aparentemente, perdas ante mortem e dos ter- ceiros molares inferiores que poderão ter sofrido perda ante mortem ou até mesmo agenese. Todas as peças dentárias preservadas exibem um desgaste dentário muito acentuado, sobretudo os molares, e depósitos de tártaro muito severos, sobretudo nas superfícies linguais. Destaca-se ainda a deteção de uma cárie de média cavidade e com origem interproximal no $1^{\circ}$ pré-molar superior esquerdo.

O indivíduo [1214] (à direita na Fig. 12) apresentava-se com o tronco em decúbito dorsal e o membro superior direito estava semifletido ao alto, num ângulo de aproximadamente $120^{\circ}$, enquanto o esquerdo se encontrava fletido num angulo de $90^{\circ}$ sobre o tórax. Os membros inferiores encontravam-se semifletidos para o lado esquerdo, com o direito a sobrepor-se ligeiramente ao esquerdo na região dos joelhos e encontrando-se sob os ossos longos dos membros inferiores do indivíduo [1213].

Este esqueleto, encontra-se completo e em excelente estado de conservação, e pertencia a um indivíduo adulto jovem com idade a morte entre os 21-30 anos. Os terceiros molares já erupcionaram mas não estão completamente formados e as extremidades esternais das clavículas ainda não entraram em processo de fusão com as diáfises.

Os ilíacos, elementos ósseos determinantes para a diagnose sexual, exibem características morfológicas tipicamente masculinas, tais como: grande chanfradura em forma de V, arco composto simples, ausência de sulco preauricular e acetabulo grande. Esta diagnose écorroborada pelas análises: morfológica ao crânio (frontal fugidio, arcadas supraciliares marcadas, inion saliente e apófises mastoides robustas) e métricas aos úmeros, fémures e astrágalos.

A análise morfológica efetuada em campo, revelou a permanência de sutura supranasal e permitiu, através dos comprimentos máximos obtidos para o úmero, fémur e tíbia esquerdos respectivamente, $310 \mathrm{~mm}, 442 \mathrm{~mm}$ e $380 \mathrm{~mm}$ determinar, para este homem, uma estatura de cerca de 163,45 cm. Uma análise paleopatologica breve revelou a presença de patologias do foro oral e degenerativo. As peças dentárias foram todas recuperadas, a exceção dos incisivos superiores e do incisivo central inferior direito que sofreram perdas post mortem, e exibem um desgaste dentário e depósitos de tártaro, de um modo geral, severos. As evidências de patologia degenerativa estão patentes sob a forma de artrose ligeira nas articulações do ombro esquerdo e do joelho, tornozelo e pé direitos e de entesopatias ligeiras a moderadas no tendão de Aquiles do calcâneo direito. 


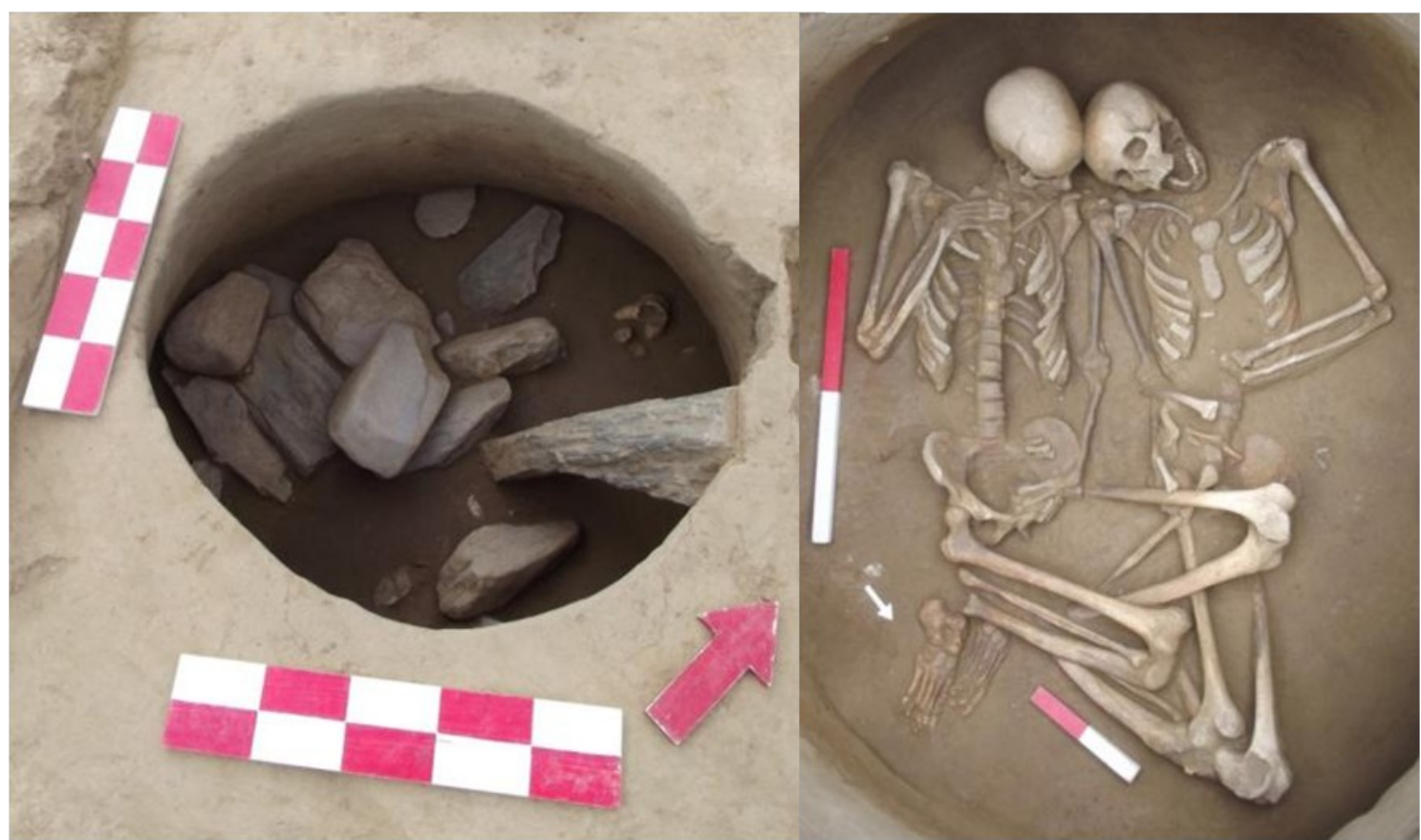

Fig. 11 e 12. Enterramentos 3 e 4. Sepultura em fossa (esquerda) e enterramento duplo de indivíduos do sexo feminino à esquerda e masculino à direita (direita)

Fig. 11 and 12. Burials 3 e 4. Pit burial (left image) and double burial (right image) of an adult female (left) and male (right).

\subsection{Enterramento 5}

Este indivíduo [1155] encontrava-se depositado na fossa 61, em posição de decúbito lateral esquerdo, numa orientação nordeste (crânio)-sudoeste (pés), com o crânio sobre o lado esquerdo e a face voltada a sudeste. Os membros superiores apresentavam-se fletidos para o lado esquerdo, com o antebraço direito a sobrepor-se ao esquerdo. $\mathrm{O}$ membro inferior esquerdo estava totalmente fletido e paralelo ao corpo e o direito fletido para o lado esquerdo, num ângulo de aproximadamente $90^{\circ}$, com o joelho a sobrepor-se ao cotovelo direito e a tíbia e o perónio sobre o antebraço direito.

$\mathrm{O}$ esqueleto encontra-se bastante completo, tendo sido recuperados os seguintes elementos ósseos: crânio, mandibula, clavículas, omoplatas, ossos longos dos membros superiores e inferiores, ilíacos e alguns fragmentos de costelas e vertebras e dos ossos do pé direito. No entanto, estas peças ósseas encontram-se em péssimo estado de conservação, ficando, aquando do levantamento, reduzidas a escassas esquírolas ou mesmo pó. Os dentes e as diáfises dos ossos longos são as regiões ósseas que melhor se conservaram, dado também serem as mais resistentes, e as epífises estão ausentes.

Trata-se de um indivíduo adulto a avaliar pela dentição, os terceiros molares estão completamente formados, e pela dimensão das peças ósseas. No entanto, a elevada fragmentação dos elementos determinantes à estimativa da idade a morte, tais como o crânio e os ilíacos, impede o acesso a um intervalo etário mais preciso. Por este motivo e dado que estes são os elementos ósseos mais discriminantes na obtenção de um diagnostico sexual, o acesso ao mesmo ficou também comprometido.
Ainda assim, em campo, a avaliação morfológica ao crânio permitiu constatar características típicas do sexo feminino (arcadas supraciliares pouco marcadas, frontal, aparentemente, vertical e inion pouco saliente).

A análise métrica, in situ, ao úmero direito, com um comprimento máximo aproximado de $264 \mathrm{~mm}$ permitiu estimar uma estatura para este indivíduo, que rondaria os $145,18 \pm 7,70 \mathrm{~cm}$. Não foram encontrados quaisquer caracteres discretos. A má conservação do esqueleto limitou a reconstrução paleopatológica. Apenas foram detetadas evidências patológicas na cavidade oral, designadamente, o desgaste dentário e os depósitos de tártaro acentuados nas peças dentárias, que permanecem, aparentemente, todas in situ. Não foram encontradas cáries.

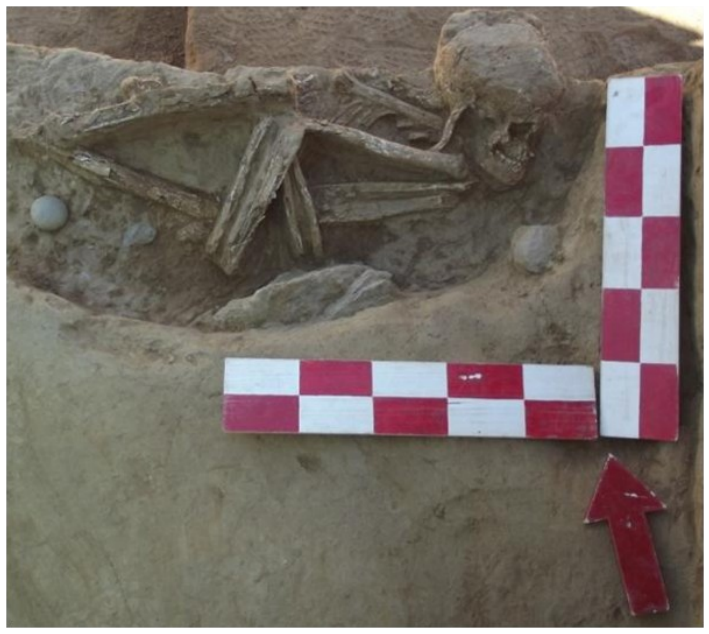

Fig. 13. Enterramento 5. Indivíduo adulto.

Fig. 13. Burial 5. Adult. 


\subsection{Síntese dos dados osteológicos}

A observação in situ deste conjunto permitiu constatar que as inumações foram efetuadas em posição de decúbito lateral, esquerdo ou direito, ou com o tronco em decúbito dorsal, seguindo múltiplas orientações (se-no, so-ne, ne-so, no-se). Registaram-se algumas variações na posição dos crânios e dos ossos longos dos membros superiores e inferiores, encontrandose maioritariamente depositados sobre ou fletidos para um dos lados. A deposição do indivíduo fez-se, num dos casos, com as costas encostadas à parede da fossa, à semelhança do verificado noutros sítios de cronologia idêntica (SANTOS et al. 2008; SANTOS et al. 2009).

A análise paleodemográfica revelou quatro indivíduos adultos, duas mulheres, um homem e um indeterminado, e um sub-adulto. A estimativa da idade à morte para o indivíduo sub-adulto foi possível com alguma acuidade, constatando-se que teria 8 a 9 anos. Os indivíduos adultos teriam idades compreendidas entre os 21 e os 40 anos.

O estudo morfológico revelou valores de estatura, que oscilam entre um valor mínimo de $160,75 \pm 8,44 \mathrm{~cm}$ e um máximo de $165,28 \pm 3,05 \mathrm{~cm}$ para o único indivíduo do sexo masculino recuperado e um mínimo de $145,18 \pm 7,70 \mathrm{~cm}$ e um máximo de $162,04 \pm 7,70 \mathrm{~cm}$ para as mulheres. No que respeita à variação não métrica destacase a deteção de foramina parietal, de perfuração esternal e de abertura septal, no indíviduo feminino [1213] e as presenças de sutura supranasal e de $3^{\circ}$ trocanter, respetivamente, nos indivíduos [1214] e [1212].

O exame paleopatológico, baseado na observação macroscópica das peças ósseas revelou algumas afeções da cavidade oral, entre as quais se destaca sobretudo o desgaste dentário acentuado, a perda ante mortem de algumas peças dentárias e o desenvolvimento de uma cárie. Embora escassos, estes indícios parecem traduzir alguma precariedade nos cuidados e hábitos de higiene oral. Apenas uma análise química dos isótopos estáveis e dos oligoelementos possibilita obter uma abordagem mais direta sobre os itens ingeridos.

No que concerne as patologias degenerativas foram registadas evidências do desenvolvimento de artrose e entesopatias, de um modo geral, não muito graves, que no entanto, e dada a reduzida dimensão da amostra não nos possibilitaram efetuar grandes ilações sobre as possíveis atividades desempenhadas pelos indivíduos exumados. Ainda assim observou-se que a frequência de artrose é ligeira sendo as lesões pouco severas o que pode testemunhar a longe- vidade breve dos indivíduos exumados e reforçar deste modo os dados da idade a morte. No entanto, os dados apresentados são preliminares e constituem apenas um breve contributo para traçar o perfil paleobiológico dos indivíduos exumados.

\section{DISCUSSÃO DOS RESULTADOS E ENQUA- DRAMENTO REGIONAL}

A ocupação do Terraço da Foz do Medal não encontra paralelo na Idade do Bronze do nordeste português. Embora o enquadramento cronológico da totalidade das inumações ainda esteja por aferir, o enterramento 2, o único datado até ao momento, insere-se no Bronze Médio. Surge, assim, pela primeira vez uma implantação de fundo de vale, a uma cota altimétrica muito baixa relativamente ao nível do curso de água e aproveitando uma ampla plataforma, de origem fluvial, com grande potencial de geração de recursos bióticos e abióticos. Este tipo de implantação é único na região, mas encontra-se bem registada no noroeste do território nacional, sobretudo datando da Idade do Bronze Médio (BETTENCOURT 2009a).

A presença de povoados de fossas encontrase, de facto, bem documentada tanto no litoral norte (SAMPAIO et al. 2008; BETTENCOURT 2009a; LUZ 2010; BotelHo 2013) como no interior alentejano (ANTUNES et al. 2012; ALVES et al. 2012; COSTA \& BAPTISTA, no prelo) no entanto, no nordeste português este tipo de ocupação era desconhecido até ao momento. Esta estratégia de implantação caracterizada pela presença de dezenas ou mesmo centenas de fossas, em terraços fluviais, ou paisagens abertas, parece ter-se banalizado após 1800 a.C. na Meseta Ibérica (ABARQUERO et al 2013). Outra questão a salientar será a seleção de locais com ocupações prévias por parte destas comunidades da Idade do Bronze (36\% dos sítios no caso das ocupações ProtoCogotas e $50 \%$ dos sítios no caso das ocupações Cogotas I). Estes sítios surgem como locais de regresso recorrente, apresentando um elevada taxa de reocupação (BLANCO 2011). Este é também o caso no Terraço da Foz do Medal. Associado a este tipo de sítios é frequente a presença de contextos funerários, situação que se verifica igualmente no vale do Sabor e que constitui um dado inédito nesta região.

Os contextos funerários já identificados em Trás-os-Montes enquadravam-se em três tipos distintos: as inumações em cista, o aproveitamento de monumentos megalíticos e os abrigos ou grutas naturais (Fig. 14). 


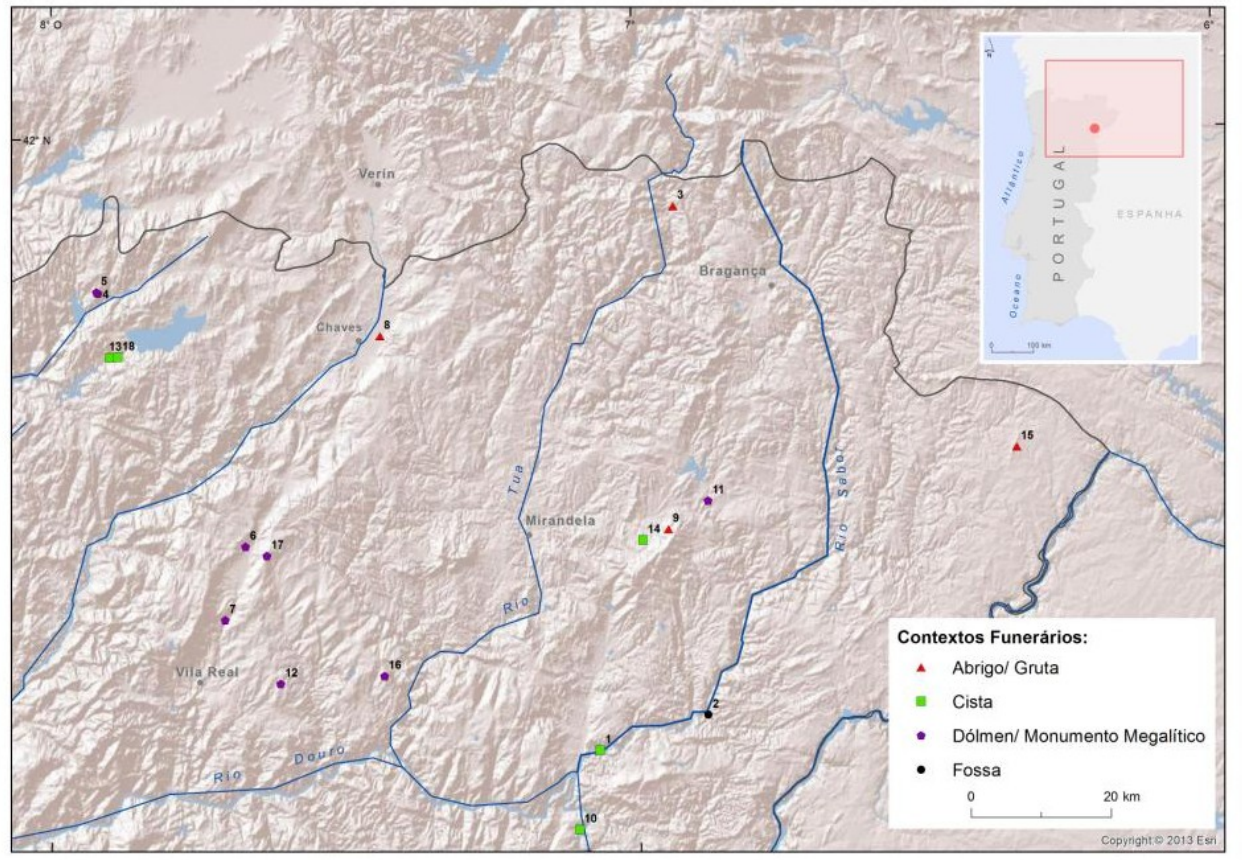

Fig. 14. Enquadramento geral dos contextos funerários pré-históricos em Trás-os-Montes, citados no texto (Cartografia Ana Rita Ferreira).

Fig. 14. Location of prehistorical funeral contexts in Trás-os-Montes, mencioned in text (map by Ana Rita Ferreira).

1-Terraço das Laranjeiras; 2-Terraço da Foz do Medal; 3-Lorga de Dine; 4-Cortelhos; 5-Fraga do Gato/Alto de Trás da Fraga; 6Ladeira Chã de Vales; 7-Alto dos Merouços; 8-Fragão da Pitorca; 9-Abrigo 2 da Fraga dos Corvos; 10 -Vale da Casa; 11-Santo Ambrósio; 12-Madorras; 13-Cista da Lomba da Fonte; 19-Cistas de Lagares; 15-Gruta de Ferreiros; 16-Estante 17-Carvalhas Alvas 1; 18-Cistas da Portela do Gorgolão.

Os dados disponíveis, relativos a sítios de natureza funerária no território contíguo ao vale, e anteriores aos trabalhos desenvolvidos no baixo Sabor remetem para a existência de uma necrópole de cistas datada do período Calcolítico e outra datada no Bronze Inicial. No primeiro caso, o Vale da Casa (Pocinho) com uma cronologia da primeira metade do III milénio a. C., apresenta várias cistas cobertas, na sua maioria, por mamoas pétreas (BAPTISTA 1983) dispostas num terraço fluvial do rio Douro. O segundo caso a necrópole de cistas de Lagares, em Macedo de Cavaleiros (BETTENCOURT 2010) enquadra-se no Bronze Inicial e apresenta sepulturas formadas por lajes de xisto. Num âmbito regional mais alargado, do Bronze Inicial e Médio referimos ainda as cistas da Lomba da Fonte (Fontela de Godim) e Cabriadas/Gorgolão (Montalegre) (BETTENCOURT 2009b, 2010).

Integrado no Bronze Final destaca-se o provável enterramento do Abrigo 2 da Fraga dos Corvos (Macedo de Cavaleiros) materializado por um conjunto material metálico de onde se destaca uma fíbula de dupla mola (SENNA MARTINEZ et al. 2006; BETTENCOURT 2009b).

Os sítios arqueológicos com contexto funerário das fases Proto-Cogotas e Cogotas I surgem amplamente representados na sub-meseta norte espanhola, em povoados de fossas, em abrigos ou túmulos megalíticos (MONTERO 2011). Este autor destaca uma série de sítios com enterramentos em fossa, da fase Proto-Cogotas, dispersos por toda esta região: o sítio de Carrelasvegas (Santillana de Campos, Palencia): Los Rompizales (Alfoz de Quintanadueñas, Burgos) com enterramento múltiplo; El Cerro (La Horra, Burgos) com enterramento triplo; Las Vegas (Jabares de los Oteros, León) e Los Tolmos (Caracena, Soria) com enterramentos individuais e triplos, localizados no interior das cabanas ou em frente destas, sendo marcante também a ausência de espólio a acompanhar o morto. Dos sítios onde também estão presentes as duas fases (incluindo a fase Cogotas I) destacam-se El juncal (Villaralbo, Zamora); Tres Chopos-Abarre (Villegas, Burgos) e Las Veguillas (Burgos), este último implantado num terraço fluvial. Inseridos na fase Cogotas I surgem enterramentos em fossa em Canto Blanco (Calzada del Coto/Sahagún, León); Tordillos (Aldeaseca de la Frontera, Salamanca); o Renedo de Esgueva (Renedo de Esgueva, Valladolid); La Requejada (San Román de la Hornija, Valladolid) em terraço fluvial e com um enterramento triplo e $\mathrm{C} /$ Obispo Manso (Zamora) (MONTERO 2011).

Os cinco enterramentos identificados no Terraço da Foz do Medal não apresentam qualquer espólio associado. Nos indivíduos não foram iden- 
tificadas quaisquer marcas de morte violenta ou doença grave. Encontra-se presente no grupo uma criança, tendo sido enterrada do mesmo modo que os adultos. Todas as situações mencionadas anteriormente enquadram-se no descrito como norma para o universo Proto-Cogotas (ABARQUERO et al. 2013). Os rituais e formas de enterramento Protocogotas e Cogotas I têm sido amplamente discutidos e novas hipóteses levantadas como a exposição de cadáveres (GONZALEZ et al. 1994; ESPARZA et al. 2012). No entanto, estas práticas não foram identificadas nos enterramentos do Terraço da foz do Medal.

O grupo Cogotas I, bem como o ProtoCogotas, caracteriza-se pela sua longa distensão temporal bem como pela sua ampla extensão territorial, ainda que apresente o seu núcleo central na bacia do Douro e setor superior da Sub-Meseta sul. Abarquero (2012) considera como zona de contato o médio e alto Ebro, o vale de Jalón, a serra de Cuenca, a margem esquerda do Tejo e o norte da Extremadura. A presença de sítios deste âmbito cultural em zona mais periféricas da Península Ibérica, como no vale do Ebro, costa mediterrânica e Andaluzia, está há muito identificada, sendo que também em território português se encontram referenciados Bouça do Frade e Tapado da Caldeira (Baião), Castelo Velho (Vila Nova de Foz Côa) e Fraga dos Corvos (Macedo de Cavaleiros) (CASTRO et al. 1995; ABARQUERO 2012; BLANCO, 2014). Estes sítios, também com fossas e enterramentos (no caso de tapado da Caldeira) deverão ser, tal como a ocupação do Terraço da Foz do Medal aqui apresentada, considerados na zona de influência da cultura. A zona de contato, bem delimitada para este e sul, deverá ser revista para oeste.

A ocupação registada no Terraço da Foz do Medal será seguramente da máxima relevância para a compreensão da Idade do Bronze do nordeste de Portugal. A presença de enterramentos em excelente estado de conservação deverá de futuro possibilitar o avanço da investigação na área do conhecimento das populações antigas, nomeadamente através da aplicação de estudos de ADN antigo e de isótopos estáveis. Por outro lado a associação de enterramentos a um conjunto de estruturas negativas de tipo fossa e a estruturas de combustão é inédita na região sendo premente repensar a Idade do Bronze à luz dos novos dados. A distribuição dos enterramentos na plataforma em relação às restantes estruturas identificadas não revela aparentemente uma estruturação espacial dos espaços de morte. No entanto, deve ser tido em conta que os processos erosivos que a plataforma sofreu após esta ocupação poderão ter truncado os vestígios da ocupação não permitindo neste momento percecionar a organização interna do espaço. Não foi identificado outro tipo de estruturas além das negativas, como sucede noutros sítios de cronologia idêntica, sendo difícil de perceber se existiria uma articula- ção dos enterramentos com espaços habitacionais.

Apesar da inexistência de espólio arqueológico associado diretamente aos enterramentos, os depósitos coluvionares que cobrem estas estruturas contêm um conjunto cerâmico, que de acordo com as suas características, se enquadra no Bronze Médio/Final. A única datação absoluta obtida até ao momento, para o enterramento 2, é consistente com o conjunto material, tal como com o tipo de implantação e a ausência de espólio associado às deposições funerárias.

\section{AGRADECIMENTOS}

Os autores gostariam de agradecer a EDP, entidade promotora do Aproveitamento Hidroelétrico do Baixo Sabor; a Baixo Sabor ACE - Odebrecht; Bento Pedroso construções S.A.; Lena construções, consórcio construtor; empresas Archeoestudos e Arqueologia e Património, parceiras na escavação arqueológica, e a todos os arqueólogos e técnicos envolvidos nos trabalhos. Um especial agradecimento para a equipa da Direção-Geral do Património Cultural pela cedência de informação cartográfica e ao colega Andrew May pela tradução para Inglês.

\section{BIBLIOGRAFIA}

AbArquero, F. J. 2012. Cogotas I más allá del território nuclear. Viajes, bodas, banquetes y regalos en la Edad del Bronce peninsular. In J.A. Rodríguez \& J. Fernández (eds.) Cogotas I. Una cultura de la Edad del Bronce en la Península Ibérica. Valladolid: Universidad de Valladolid, 59-110.

Abarquero, F. J.; BlanCo-GonZÁlez, A.; EsParza, A. \& Rodriguez, J. A. 2013. The Central Iberian Meseta at the time of the Thera-eruption: an overview. Tangungen des Landesmuseums für Vorgeschichte Halle, Band 9: 315-326.

Antunes, A. S.; Deus, M.; SoARES, A. M. M.; SAntos, F.; ArÊZ, L.; DewUlF, J.; BAPTISTA, L. \& OliVeirA, L. 2012. Povoados abertos do Bronze Final no médio Guadiana. In J. Jiménez (ed.) Sidereum Ana II. El rio Guadiana en el Bronze Final [Anejos de AEspA LXII]. Mérida: Consejo Superior de Investigaciones Científicas, Junta de ExtremaduraConsorcio de Mérida, 277-308.

Alves, C.; Costeira, C.; Eestrela, S.; Porfírio, E. \& SERrA, M. 2012. Torre Velha 3 (Serpa). Dados preliminares. Al Madam on line, 17 (1), $2^{\mathrm{a}}$ série: 31 -38. http://www.almadan.publ.pt

BAPTISTA, A.M. 1983. O complexo de gravuras rupestres do Vale da Casa (Vila Nova de Foz Côa). Arqueologia, 8: 57-69.

Bettencourt, A.M.S. 2009a. A Pré-História do Minho: do Neolítico à Idade do Bronze. In P. Pereira (coord.) Minho. Traços de Identidade. Braga: Conselho Cul - tural da Universidade do Minho, 70-113.

Bettencourt, A.M.S. 2009b. Práticas funerárias da Idade do Bronze de Trás-os-Montes e da Galiza oriental. Actas do $1^{\circ}$ Congresso Transfronteiriço de Arqueologia (Montalegre, 2008) [Revista Aquae Flaviae 41]: 11-23. 
Bettencourt, A.M.S. 2010. La Edad del Bronce en el Noroeste de la Península Ibérica: un análisis a partir de las prácticas funerarias. Trabajos de Prehistoria, 67 (1): 139-173.

Blanco, A. 2011. Práctica social, memoria y ritual en Cogotas I: esbozo teórico para un enfoque renovado. Trabajos de Prehistoria, 68 (1): 123-146.

BlANCO, A. (2014). Sitios en altura y vasijas rotas: reconsiderando la "plenitud" de Cogotas I (1450-1150 cal AC) en la Meseta. Trabajos de Prehistoria, 71 (2): aceite e no prelo.

BLASCO, M.C. 1997. La Edad del Bronce en el interior peninsular. Una aproximación al II milenio a.C. en las cuencas de los ríos Duero e Tajo. CuPAUAM, 24: 59-100.

Blasco, M.C.; Sanches, M.L.; Calle, J.; Robles, F.J.; GonZALEZ, V.M. \& GonZALEZ, A. 1991. Enterramientos del horizonte Protocogotas en el valle del Manzanares. CUPAUAM, 18: 55-112.

Botelho, I. 2013. O sítio do Corgo. Uma estação da Idade do Bronze em Vila do Conde. In J. Arnaud; A Martins \& C. Neves (eds.) Arqueologia em Portugal. 150 anos. Lisboa: Associação dos Arqueólogos Portugueses, 581-589.

Castro, P.V.; Mico, R. \& Sanahuja, M.E. 1995. Genealogía y cronología de la "cultura de Cogotas I" (El estilo cerámico y el grupo de Cogotas I en su contexto arqueológico). Boletín del Seminario de Estudios de Arte y Arqueología, 61: 51-118.

CostA, C. \& BAPTISTA, L. no prelo. The inclusion of faunal remains in Bronze Age funerary practices Portugal. Montinhos 6. A case study, In C. Detry \& R. Dias (eds.) Proceedings of the I Congresso International de Zooarqueologia. Lisbon, 8-9 March, 2012. B.A.R. series, Oxford: Archaeopress.

Esparza, A.; Velasco, J. \& DeliBes, G. 2012. Exposición de cadáveres en el yacimiento de Tordillos (Aldeaseca de la Frontera, Salamanca). Perspectiva bioarqueológica y posibles implicaciones para el estudio del ritual funerário de Cogotas I. Zephyrus, 69: 95-128.

FERREIRA, A.B. 2005. Formas de relevo e dinâmica geomorfológica. In C.A. Medeiros (dir.) Geografia de Portugal. O Ambiente Físico. Vol. 1. Rio de Mouro: Círculo de Leitores, 53-256.

FigueIREDO, S.S. 2013. A Arte esquemática do Nordeste Transmontano: contextos e linguagens. Braga: Universidade do Minho (Tese de Doutoramento-Policopiada).

Figueiredo, S.S.; Nobre, L.; GaSPAR, R.; CARRONDO, J.; Cristo-Ropero, A.; Ferreira, J.; Silva, M.J.D. \& MolinA, F.J. 2014. Foz do Medal terrace. A open-air settlement with Paleolithic mobile art, INORA - International Newsletter on Rock Art, 68.

GASPAR, R. no prelo. O vale do Sabor enquanto palco de mudança. O caso de Mogadouro. Atas do I Encontro da Arqueologia de Mogadouro, 19 de abril de 2013. Mogadouro: Câmara Municipal.

GonZÁleZ-TABlas, F.J. \& FANO, M.A. 1994. El fenómeno de la muerte en Cogotas I: una propuesta metodológica. Zephyrus, 47: 93-103.

LUZ, S. 2010. O depósito de conchas do sítio arqueológico das Areias Altas (Porto, Portugal). Discussão do enquadramento arqueológico da estrutura 15. In $\mathrm{E}$ González \& V. Fernández (coord.) I Reunión Científica de Arqueomalacología de la Península Ibérica. León, 20-21 de Maio.[Férvedes 6]:141-145.
MonTERO, J. 2011. Manifestaciones rituales e ideología durante la Edad del Bronce en el interior peninsular. La dimensión social de las prácticas funerarias de Cogotas. Burgos: Universidad de Burgos (Tese de doutoramento-Policopiada).

PEREIRA, D.I. \& AZEVÊDO, T.M. 1995. Evolução quaternária do Graben da Vilariça (Trás-os-Montes, NE Portugal). Caderno do Laboratório Xeolóxico de Laxe, 20:123-137.

PereirA, E.; Ribeiro, A.; Rebelo, J.A. \& CAStro, P. 2008. Noticia explicativa da Folha $11 B$ - Mogadouro. Lisboa.Laboratório Nacional de Energia e Geologia.

Prieto, M.P.; MARtíneZ, A.; LANTES, O. \& AgRA, G.D. 2009. Estudio de la cerâmica del yacimiento de fosas de Fraga do Zorro. Actas do 10 Congresso Transfronteiriço de Arqueologia (Montalegre, 2008). [Revista Aqvae Flaviae 41]: 107-121.

REIMER, P.J.; BARD, E.; BAYLISS, A.; BECK, J.W.; BLACKWEL, P.G.; BRONK RAMSEY, C.; BUCK, C.E.; CHENG, H.; EDWARDS, R.L.; FRIEDRICH, M.; GROOTES, P.M.; GUILDERSON, T.P.; HAFLIDASON, H.; Hajdas, I.; Hatté, C.; Heaton, T.J.; HogG, A.G.; Hughen, K.A.; KAISER, K.F.; Kromer, B.; MAN NING, S.W.; NIU, M.; REIMER, R.W.; RICHARDS, D.A.; SCOTT, E.M.; SOUTHON, J.R.; TURNEY, C.S.M. \& PLICHT, J.V. 2013. IntCal13 and MARINE13 radiocarbon age calibration curves 0 50000 years calBP. Radiocarbon, 55 (4):18691887.

SAMPAiO, H.; BetTencourt, A.M.S.; BARBosA, R.; Dinis, A \& CRUZ, C. 2008. A importância do povoado do Pego no Bronze Final do Noroeste de Portugal. In E. Ramil Rego (ed.) Actas do I Congreso Internacional de Arqueoloxia de Vilalba (Vilalba, 2008). [Férvedes, 5]: 227-233.

Santos, F.; Monge, A.M.; Rodrigues, Z.; QueIroz, P.F.; VALÉrio, P. \& ARAúJo, M.F. 2009. A Horta do Albardão: um sítio da Pré-História Recente, com fosso e fossas, na encosta do Albardão (S. Manços, Évora). Revista Portuguesa de Arqueologia, 12 (1): 53-71.

SAntos, F.; Arez, L.; SoARES, A.; Deus, M.; QueIroz, P VALÉRIO, P.; RoDRIgUes, Z.; ANTUNES, A. \& ARAúJo, M. 2008. O Casarão da Mesquita 3 (S. Manços, Évora): um sítio de fossas "silo" do Bronze Pleno/Final na encosta do Albardão. Revista Portuguesa de Arqueologia, 11 (2): 55-86.

SASTRE, J. no prelo. Da Idade do Ferro à romanização da área de Crestelos. Atas do I Encontro da Arqueologia de Mogadouro, 19 de abril de 2013. Mogadouro: Câmara Municipal.

Senna-Martinez, J.C.; Ventura, J.; Carvalho, H. \& FigueIREDO, E. 2006. A Fraga dos Corvos (Macedo de Cavaleiros): um sítio de habitat da primeira Idade do Bronze em Trás-os-Montes oriental. A Campanha 3 - 2005. Cadernos Terras Quentes, 3 : 61-85.

Silva, A.F.; Rebelo, J.A. \& Ribeiro, M.L. 1989. Notícia explicativa da Folha 11C - Torre de Moncorvo. Lisboa: Serviços Geológicos de Portugal.

Trindade, A.R.; Correia, M. \& Lourenç, R. 2012. Capela de Santo Antão. Boletim da Associação de Fiéis "Confraria de Santo Antão da Barca", 1: 4-5. 